\title{
INFECTIOUS MYONECROSIS VIRUS (IMNV) IN PACIFIC WHITE SHRIMP, Litopenaeus vannamei IN INDONESIA
}

\author{
Taukhid"), and Yani Lestari Nur'aini ${ }^{* *}$
}

\begin{abstract}
The aquaculture industry in Indonesia has been growing rapidly and plays an important role in rural development and export earning. Penaeid shrimp culture in Indonesia has become a leading export earning in fisheries sector. The main constraint encountered with shrimp culture has always been associated with disease outbreaks, especially, caused by viral agents. The Pacific white shrimp (Litopenaeus vannamei) was unofficially introduced to Indonesia in 1999, and officially approved by Indonesian government in 2001. By the end of 2007, the Pacific white shrimp has been cultured in more than 17 provinces. The Taura Syndrome (TS) disease was detected in Indonesia in 2002, and the disease is currently found in at least 10 provinces. The Infectious Myonecrosis (IMN) is an emerging disease for L. vannamei in Indonesia, first detected in May-June 2006, causing significant mortalities in grow-out ponds. The IMN is characterized by an acute onset of gross signs: focal to extensive whitish necrotic areas in the striated muscle, especially on the distal abdominal segments and tail fan. White necrotic areas become reddened similar to the color of cooked shrimp. The outbreak resulted in elevated mortalities was initially associated with a chronic course of persistent low level mortalities. Up to date, IMN was detected in East Java, Bali, and West Nusa Tenggara provinces. This paper is a brief review of the epidemiological study of IMN disease of Pacific white shrimp in Indonesia: the status of outbreaks, surveillance $\&$ disease diagnosis, and control measures.
\end{abstract}

\section{KEYWORDS: disease, IMN, Pacific white shrimp (Litopenaeus vannamei),} Indonesia

\section{INTRODUCTION}

The Pacific white shrimp, Litopenaeus vannamei was initially introduced in Indonesia in 1999 as an alternative species for aquaculture besides the local shrimp species Penaeus monodon and P. merguensis. The Government of Indonesia allowed importation of Pacific white shrimp in 10 October, 2000 for research purposes only. The exotic shrimp was imported from Taiwan, and Hawaii. Based on the Ministerial Decree No. 4/2001 dated 14 July 2001 , Pacific white shrimp was allowed to be imported for culture purposes. Futhermore, in order to protect the sustainability of the Pacific white shrimp industry in Indonesia, only good quality and TSV-free broodstocks are approved for importation.

Hence, by the end of 2007 , L. vannamei have been cultured in at least 17 provinces (East Java, Central Java, West Java, Yogyakarta, Banten, Bali, West Nusa Tenggara, Lampung, South Sumatra, Riau, Bengkulu, West and North Sumatra, South Sulawesi, South Kalimantan, and East and West Kalimantan). Since 2002, the main constraint encountered with Pacific white shrimp culture in Indonesia has always been

\footnotetext{
) Research Institute for Freshwater Aquaculture, Bogor, Indonesia

**) Brackishwater Aquaculture Development Center, Situbondo, East Java
} 
associated with disease outbreaks, especially, caused by viral agents. In early 2003 , a serious disease outbreak occurred in northern East Java. The causative agent of the disease was Taura Syndrome Virus (TSV) and it was the first detected TSV outbreak in Indonesia. The disease was most likely brought in through illegal importations of L. vannamei from sources/countries that have history of TSV outbreaks. Since then the disease subsequently had dispersed to uninfected areas. By 2007, the disease was detected in at least 10 provinces where the Pacific white shrimp was being cultured.

In the middle of 2006, there were anecdotal reports of disease outbreak in Pacific white shrimp culture in Situbondo district with gross signs of white muscle, similar to the Infectious Myonecrosis Virus (IMNV) outbreaks in Brazil (Senapin et al., 2007). Subsequent analysis revealed that the Indonesian IMNV sample had $99.6 \%$ nucleic acid sequence identity (a total of 29 differences in $7.5 \mathrm{~kb}$ ) to that of Brazilian IMNV reported at GenBank (Senapin et al., 2007). At present, four significant viral diseases have been reported on cultured $\mathrm{Pa}$ cific white shrimp in Indonesia, namely: White Spot Syndrome Virus (WSSV), Taura Syndrome Virus (TSV), Infectious Hypodermal and Hematopoietic Necrosis Virus (IHHNV), and Infectious Myonecrosis Virus (IMNV) (Taukhid, unpublished data). This report presents the epidemiological data on the surveillance of outbreaks, disease diagnosis, control measures of IMN in Pacific white shrimp culture, in Indonesia.

\section{MATERIALS AND METHODS}

Surveillance. The survey of IMNV was conducted in 2006 and 2007. The survey was focused in high risk areas of East Java and neighboring provinces: Bali and West Nusa Tenggara. Sampling sites (spot areas) were identified based on development and intensity of Pacific white shrimp culture in the surveyed provinces. The surveillance design was developed according to the Standard Survey Toolbox for Aquatic Animal Diseases (Cameron, 2002).

Shrimp farmers were identified through stratified random sampling based on the latest records of Fisheries Service Agency in district level, and then were sampled randomly at the defined spot areas. In addition, semi structured questionnaires were used to collect information from respondents. Data collection and other information were focused mainly on the status of IMNV outbreaks and control measures applied.

Sampling and diagnostic techniques. Shrimp samples were taken from hatcheries and grow out ponds in three spot areas of each district, representing a sampling site. Sample size of post larvae (PLs) was 100-150 shrimp, and 30 for adult shrimp (grow out). The PLs obtained from the same population was pooled, and then preserved in $80 \%$ alcohol mixed with $20 \%$ glycerol in the same bottle. Adult shrimp samples with obvious clinical signs as described by Poulos and Lightner (2006), were taken from IMN-suspected ponds and preserved individually in $80 \%$ alcohol mixed with $20 \%$ glycerol.

Diagnosis was based on level I, level II, and level III diagnosis. Level I diagnosis included behavioral, clinical signs, and type of mortality rate. Level II diagnosis focused on histopathology of infected shrimp. Level III diagnosis was done by polymerase chain reaction (PCR) using IMNV IQ2000 TM Detection and Prevention System (Farming Intelligene Tech. Corp.). Shrimp muscle tissue from the $6^{\text {th }}$ abdominal segment or gill were homogenized in Trizol reagent (Invitrogen) and RNA was extracted according to the manufacturer's instructions. Adult shrimps, prior to detection for IMNV infection, were analyzed using pooled sample of 5-10 shrimps per test. If the result was positive, further analysis was done on individual shrimp sample. However, if the result was negative, no further tests were required.

\section{RESULTS}

Surveillance. The result of the IMNV survey conducted in 2006 and 2007 showed that the virus spread rapidly, and has serious potential to spread widely in the country. The IMNV distribution was initially restricted in Kapongan municipal, Situbondo district, East Java province in July-August 2006 (Fig. 1). However, by the end of 2007, the virus was detected in shrimp production centers in East Java, and in western Bali and West Nusa Tenggara (Fig. 2).

Level I diagnosis. General indicators of Pacific white shrimp infected by IMNV consisted of lethargy, loss of balance, swimming on the water surface at day time, abrupt decrease in feeding rate of infected shrimp, development of whitish necrotic areas in the stri- 


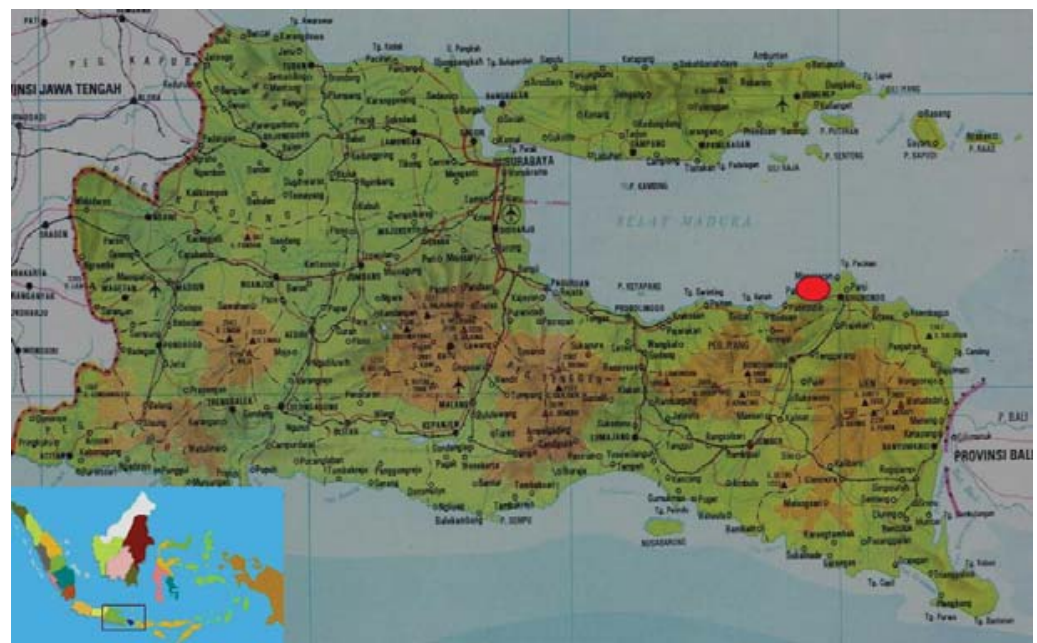

Figure 1. Geographical distribution of Infectious Myonecrosis Virus (IMNV) in East Java and Bali in July-August, 2006

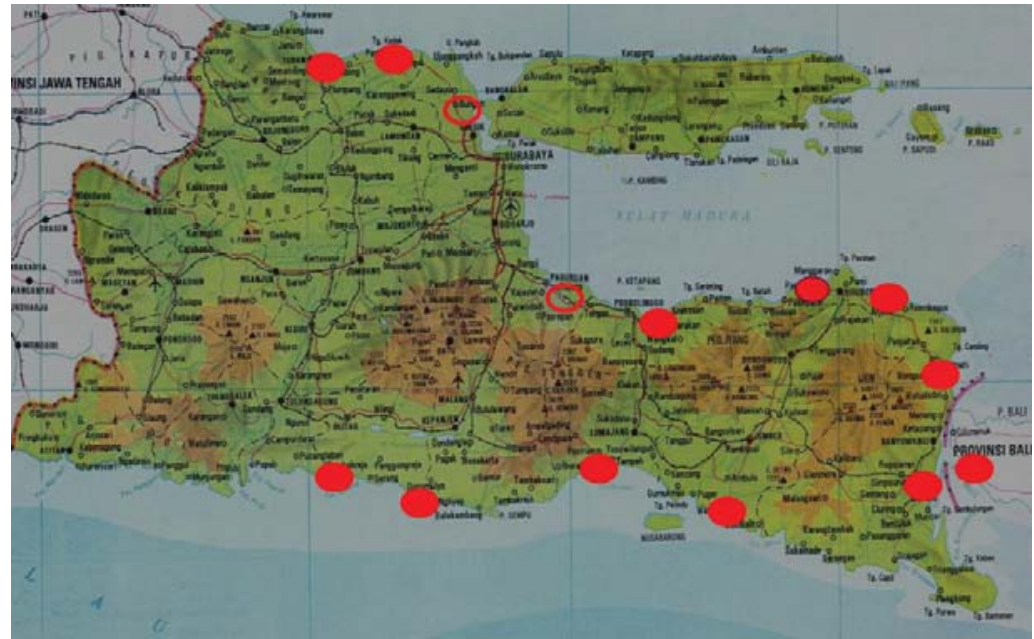

Figure 2. Geographical distribution of Infectious Myonecrosis Virus (IMNV) in East Java and Bali by the end of 2007. (the red circles are surveyed areas and IMNV-negative areas, and the solid red circles are surveyed and IMNV-positive areas )

ated muscles that became reddened similar to cooked shrimp, followed by elevated mortalities. These clinical signs may have a sudden onset following stresses e.g. sudden changes in temperature or salinity. Severely affected shrimp may have been feeding just before the onset of stress and will have a full gut. Such severely affected shrimp became moribund and mortalities could be instantaneously high and continue for several days. Generally, the dis- ease outbreak was indicated by elevated mortality rate, and progresses to a more chronic course accompanied by persistent low level mortalities (250 - 5,000 shrimps/day). The only consistent and pathognomonic clinical sign of the disease was the focal to extensive whitish necrotic areas in the striated muscle, especially on the distal abdominal segments and tail fan. The white necrotic areas became reddened similar to the color of cooked shrimp. 

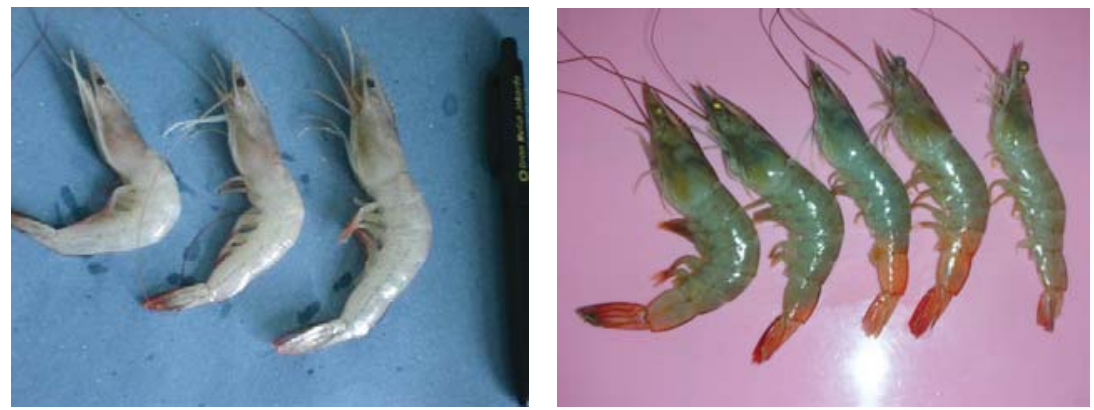

Figure 3. Clinical signs of Pacific white shrimp infected by Infectious Myonecrosis Virus (IMNV) showing focal to extensive whitish necrotic areas in the striated muscle (left), and white necrotic areas becoming reddened similar to the color of cooked shrimp (right)

Therefore, these clinical signs were used for the presumptive diagnosis of IMN disease (Fig. $3)$.

Level II diagnosis. Infected shrimps with acute disease presented lesions with coagulative muscle necrosis, often with edema. In shrimp recovering from acute disease or in the more chronic phase of the disease, the myonecrosis appeared to progress from coagulative to liquefactive necrosis. This progression of myonecrosis was accompanied by hemocytic infiltration and fibrosis. The typical histological changes due to IMNV infection are shown in Fig. 4.

Level III diagnosis. The results of PCR analyses of shrimp samples collected during the first outbreak in Situbondo district (2006) showed that the intensity of the viral infection ranged from light to moderate infection accord- ing to the IMNV IQ2000 ${ }^{\text {TM's }}$ kit interpretation chart (Fig. 5).

It was noted that although PL samples collected in 2006-2007 were IMNV-negative, when reared in grow out ponds exhibited IMN outbreaks which were confirmed IMN-positive by PCR test before harvesting. Similar phenomena have occurred in all subsequent crops during the dry and rainy seasons up until now.

In addition, shrimp samples collected during the designed survey conducted in JulySeptember 2007 showed that all samples have light IMNV infection. The profile of PCR product of IMNV diseased shrimps collected from major infected areas (Probolinggo and Banyuwangi) are shown in Fig. 6.

Status of outbreaks. The first IMN outbreak in Indonesia was reported in Kapongan
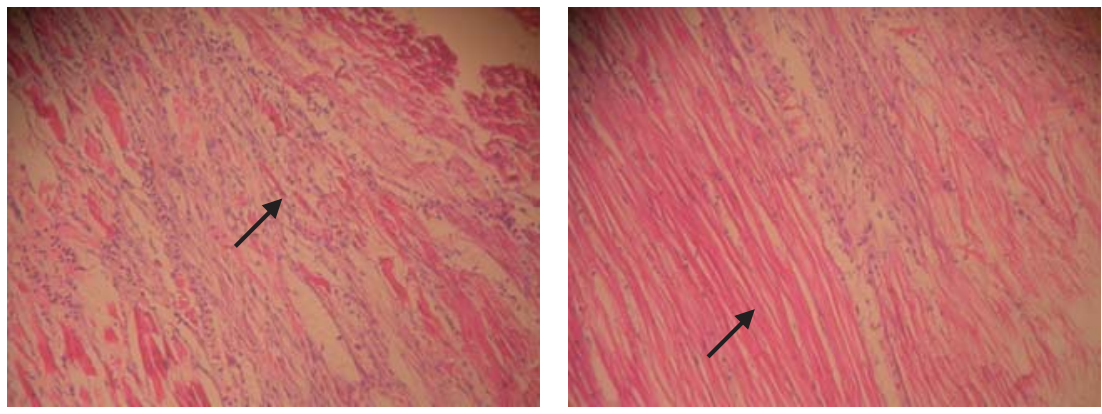

Figure 4. Histological changes of Pacific white shrimp infected by Infectious Myonecrosis Virus (IMNV). Myonecrosis, accompanied by hemocytic infiltration and fibrosis (left). Note the normal skeletal muscle observed in the lower left corner (right) (hematoxylin/eosin stain; magnification 100X) 


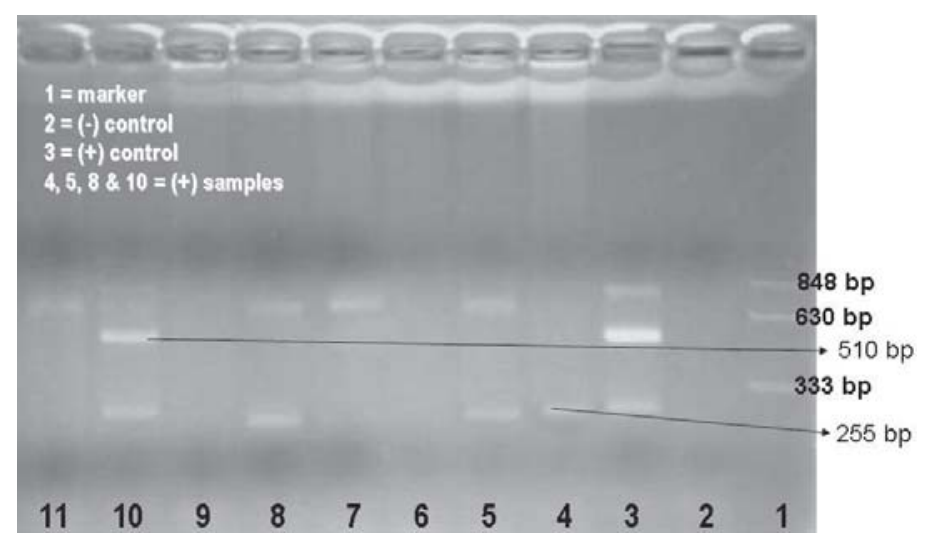

Figure 5. Profile of polymerase chain reaction (PCR) products of Pacific white shrimp samples collected during the first outbreak of Infectious Myonecrosis (IMN) disease (MayJune 2006) in Indonesia
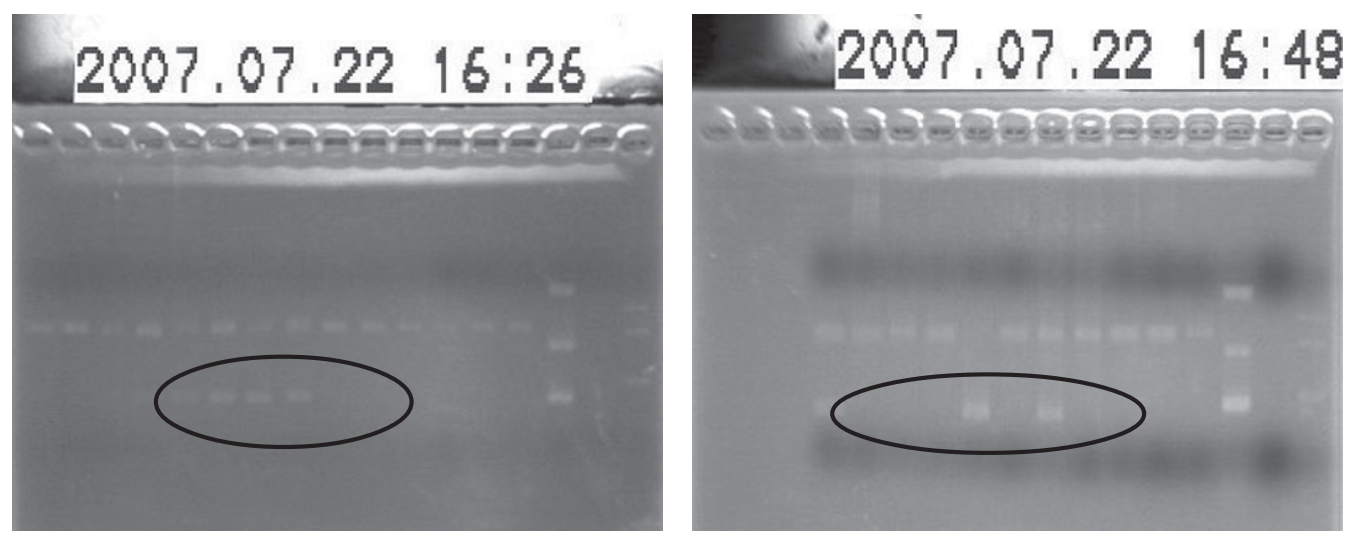

Figure 6. Profile of polymerase chain reaction (PCR) products of Pacific white shrimp samples infected by Infectious Myonecrosis Virus (IMNV) collected from Probolinggo (left), and Banyuwangi (right)

municipal, Situbondo district, East Java, in MayJune 2006. It occurred in shrimps that had been cultured for more than 70 days in the ponds, causing mortalities of $10-30 \%$. The PLs originated from a hatchery in Situbondo, a district well known as one of the centers for penaeid shrimp hatchery in Indonesia. In July - August 2006, disease outbreaks with similar clinical signs were reported from shrimp farms located near the site where the first IMN outbreak occurred. Since then, IMN outbreaks spread to shrimp ponds in neighbouring areas.

The IMN outbreaks caused significant mortalities in juvenile and subadult pond reared stocks. It usually occurred in grow out ponds at 30 - 90 days of culture (DOC), and the outbreak is not seasonal dependent. Mortality rates due to IMN could only be $10-30 \%$. However, if TSV infection occurred first and accompanied by IMN infection, mortality rate could be larger than $40 \%$. In 2006 , the IMN outbreaks were restricted to shrimp farms located in Situbondo district. But by mid of 2007, IMN outbreaks were reported in other districts of East Java.

Furthermore, according to the farmers, the IMN outbreaks were observed mainly in the shrimp farms without reservoir ponds. However, occasionally, IMN outbreaks may also occur in shrimp farms with reservoir ponds. It 
was observed that in IMN endemic areas, the disease usually occurred earlier in shrimp farms without reservoirs, and can even spread to shrimp farms with reservoir ponds. IMN outbreaks in 2006 mainly occurred in Pacific white shrimp cultured for 70 days in ponds. However, IMN outbreaks recently occurred in DOC 30 of white shrimp cultured in ponds.

A number of shrimp farmers that experienced IMN outbreaks stated that the disease occurred in any crop season. Interestingly, from information gathered during the surveillance study, it was found that PLs produced from imported broodstock (SPF) seemed to be more resistant to IMNV infection; but, relatively sensitive to TSV infection. On the other hand, PLs produced from domesticated (local) broodstock seemed to be sensitive to IMNV infection; but, relatively resistant to TSV infection. Unfortunately, both TSV and IMNV were always detected in all districts of East Java. Information on the IMN outbreaks in 3 shrimp farms located in Situbondo district are summarized in Table 1.

Control measures. Along with the recent increase in Pacific white shrimp (broodstock/ post larvae/shrimp product) traffic in the country, there is an increase risk of introduction and distribution of shrimp pathogens throughout the country. In response to IMN outbreaks in the country, number of strategies to control the disease were recommended.
As soon as the viral infection is confirmed in a farm, it is usually quarantined and the infected ponds is disinfected in order to prevent further contamination of other ponds in the farm. In the early stage of infection indicated by a very low mortality rates, control measures routinely practised by shrimp farmers includes: (1) stabilizing water quality parameters, especially water temperature, salinity and $\mathrm{pH}$; (2) increasing aeration as much as possible; (3) applying feed additive (microencapsulated ascorbic acid); (4) applying sugar molasses ( $25 \%$ of feeding rate/day) or probiotic, and (5) decreasing or stopping feeding for a while.

In the case of disease outbreak with acute onset of gross signs and elevated mortalities, with persistent low level mortalities; emergency harvest is recommended if the shrimps have reached marketable size. Shrimp pond and all of its contents (water, aeration system, feeding trays, etc.) must be disinfected by applying chlorine more than $30 \mathrm{ppm}$ for several days. Once the virus has been eradicated from a site, it is important to prevent re-introduction. It is likely that infection is spread by infected shrimp/post larvae, as well as by contaminated water and equipment. Accordingly, the following measures should be considered: post larvae and broodstock should be obtained from reliable IMNV-free sources; all potential carriers must be rigorously excluded from farms in endemic areas; water and equipment

Table 1. Occurrence of Taura Syndrome (TS) and Infectious Myonecrosis (IMN) diseases outbreaks in Pacific white shrimp in three shrimp farms in Situbondo in 2007

\begin{tabular}{|c|c|c|c|c|c|c|c|}
\hline \multirow{3}{*}{ Period } & \multirow{3}{*}{$\begin{array}{l}\text { No. of } \\
\text { ponds }\end{array}$} & \multicolumn{2}{|c|}{ Postlarvae source } & \multicolumn{4}{|c|}{ Disease outbreak } \\
\hline & & \multirow{2}{*}{$\begin{array}{l}\text { Local } \\
\text { (L) }\end{array}$} & \multirow{2}{*}{$\begin{array}{l}\text { Import ed } \\
\text { (I) }\end{array}$} & \multicolumn{2}{|c|}{ Taura Syndrome } & \multicolumn{2}{|c|}{$\begin{array}{l}\text { Infectious } \\
\text { Myonecrosis }\end{array}$} \\
\hline & & & & $\mathrm{NP} / \mathrm{S}$ & DPS & $\mathrm{NP} / \mathrm{S}$ & DPS \\
\hline \multirow{2}{*}{ Jun-Jul } & \multirow{2}{*}{18} & \multirow{2}{*}{10} & \multirow{2}{*}{8} & $3 / 1$ & 30 & $1 / 1$ & 80 \\
\hline & & & & $1 / L$ & 40 & $7 / L$ & 60 \\
\hline \multirow{2}{*}{ Aug-Sept } & \multirow{2}{*}{26} & \multirow{2}{*}{15} & \multirow{2}{*}{11} & $4 / 1$ & 30 & $2 / 1$ & 90 \\
\hline & & & & $2 / L$ & 40 & $9 / L$ & 75 \\
\hline \multirow{2}{*}{ Oct-Nov } & \multirow{2}{*}{20} & \multirow{2}{*}{12} & \multirow{2}{*}{8} & $1 / 1$ & 30 & - & - \\
\hline & & & & $1 / L$ & 30 & $4 / L$ & 60 \\
\hline
\end{tabular}

\footnotetext{
Local $(\mathrm{L}) \quad=$ seed produced from local/domesticated broodstock

Imported $(\mathrm{I})=$ seed produced from imported broodstock

$\mathrm{NP} / \mathrm{S}=$ number of pond/source of PLs

DPS $\quad=$ days post stocking
} 
which may have been used at infected sites must be disinfected.

Prevention. Since there is no effective treatment for IMNV infection, shrimp farmers can only protect the farms and shrimp by preventing the disease. Shrimp farmers need to start building up knowledge about it such as the source of this pathogen by screening of the seeds, the waterborne crustaceans, plankton and the relationship between the viral load and the onset of clinical signs to determine the timing of harvesting. It is strongly suspected that IMNV can be transmitted horizontally and vertically. Therefore, the virus can be potentially transmitted from broodstocks to nauplii, from live feed, other animals, cannibalism behavior, sharing tools, etc. When a virus is easily carried into the culture environment, all potential carriers are to be screened and those infected with the disease can be discharged. To prevent vertical transmission of the virus, all broodstocks must be screened. To block horizontal transmission of the virus, only virus-free PLs must be stocked and good management practices must be followed. The key to a successful prevention is to take action as fast as possible.

The use of SPF Pacific white shrimp represents an important development of shrimp culture. However, the fact that non-SPF $L$. vannamei is being used in the country can lead to the emergence of several health problems. Transboundary movement of broodstock still plays a major role in the spread of shrimp pathogens. The practice of holding broodstock of different species in the same holding space by brokers should therefore be avoided.

Regulations. The IMN has been added to the list of diseases under the National Fish Quarantine through the Ministerial Decree No. $17 / 2006$. This decree was issued to protect the country from the introduction such exotic disease and prevent wider spread of IMNV from infected zones to uninfected ones. It is hoped that awareness of this newly emerging pathogen will motivate shrimp farmers and governmental authorities to heighten measures against its further spread in the country.

\section{DISCUSSION}

The occurrence of IMNV infection in Pacific white shrimp in Indonesia was confirmed after sequencing the PCR fragment of IMNV from shrimp sample that originated from
Situbondo district, East Java (Senapin et. al., 2007). Subsequent analysis revealed that the Indonesian IMNV had $99.6 \%$ nucleic acid sequence identity to that of the Brazilian IMNV reported at the GenBank (GenBank accession No. EF061744).

The IMN outbreak in Indonesia was first recorded in Situbondo district, East Java, in 2006, affecting $>70$ DOC Pacific white shrimp cultured in grow out ponds, with mortalities of 10 $30 \%$. The seed originated from a hatchery in Situbondo. The IMN disease outbreak caused significant mortalities in juvenile and subadult pond reared stocks. It usually occured in 3090 DOC in grow out ponds, and outbreak did not appear to be season dependent. Geographical distribution of the IMNV in Indonesia was spreading faster and disease control program has little success in preventing it. Situbondo and Banyuwangi are endemic for IMNV and also the biggest producers of penaeid shrimp larvae/PL's (including Pacific white shrimp) in the country. Therefore, the disease had serious potential of spreading in the country. It is still unclear what trigger the disease transmission. However, it is strongly suspected that transmission of the disease was mainly through shrimp broodstock and post larvae movements.

Recently, the IMNV was detected in Pacific white shrimp farms located in South Kalimantan (Supriyadi, pers. commun.) and the seed used in these farms originated from Situbondo (East Java). It was also shown that infected post larvae/broodstock, and contaminated shrimp ponds/water supplies were the most likely the sources of IMNV infection. A number of risk factors may play a role in disease development such as water quality and feeding management. Outbreak of the disease was strongly associated with certain types of water quality parameters such as algal bloom, extremes fluctuation of salinity, $\mathrm{pH}$, temperature, and possibly the use of low quality feeds (Poulos et al., 2006). In Indonesia, it was known that PLs produced from imported broodstock (SPF) seem to be resistant to IMNV infection; but, relatively sensitive to TSV infection. On the other hand, PLs produced from domesticated (local) broodstock seemed to be more sensitive to IMNV infection; but, relatively resistant to TSV infection.

As the outbreak continued, various clinical signs were observed or reported. However, the only consistent clinical sign of the 
disease as described by Poulos \& Lightner (2006) were a focal to extensive whitish necrotic areas in the striated muscle, especially on the distal abdominal segments and tail fan. White necrotic areas become reddened similar to the color of cooked shrimp. Therefore, those pathognomonic clinical signs were used to establish a Level I presumptive diagnosis of IMN disease.

During disease outbreaks, most shrimp farmers preferred to use behavior, clinical signs, mortality rate, and PCR diagnostic methods to confirm the presence of IMNV infection. Up to date, the methods mentioned above are the practical and popular options to diagnose the disease. Since, histopathology is time consuming and requires a well-trained shrimp pathologist, this method is mainly used for confirmatory diagnosis.

Unstable test results of IMNV PCR detection during the 2006 and 2007 outbreaks were attributed to many factors that could affect the sensitivity and specificity of the diagnostic kit. As the detection of IMNV in Indonesia using PCR assay is still in developmental stage, a standardized and harmonized of PCR application is urgently needed to ensure high quality results.

Up to date, there is no accurate data on economic losses due to IMN disease outbreaks in Pacific white shrimp in the country. However, there are many reports from farmers about financial loss as a result of disease outbreaks. Concerns were voiced on the need to address the issue and of support from the government on disease control programs, including restrictions on movement of live shrimp from infected zones to uninfected ones.

There was no clear information, how the disease originally came into Indonesia. The government of Indonesia was strongly recommended that importation of Pacific white shrimps for culture purposes were restricted only from Hawaii and Florida (USA). Senapin et al. (2007) suspected that L. vannamei broodstock or PLs from Brazil were smuggled into Indonesia for use in a commercial hatchery. If this is true, it may explain the relatively close identity of the genome sequences of IMNV from Indonesia and from Brazil and may constitute another example of the unfortunate transfer of shrimp pathogens over large geographical distances by careless movement of contaminated stocks for aquaculture. Further- more, Flegel (2006) stated that many viral pathogens are restricted in their geographical distribution and their spread to new areas can have disastrous consequences. It is believed that unregulated transboundary movement of shrimp broodstock, postlarvae, and shrimp products is the major cause of pathogen spread between regions.

Along with the recent increase in Pacific white shrimp broodstock/post larvae/shrimp product traffic in the country has increased the risk of introduction and distribution of shrimp pathogens throughout the country. Suggestions to control the disease such as the use SPF seed; screening of the seed, the waterborne crustaceans and plankton; the relationship between the viral load and the clinical signs to determine the timing of harvesting; and the implementation of the Ministerial Decree No. 17/2006 will help towards realizing IMNV-free areas in the future.

\section{REFERENCES}

Cameron A. 2002. Survey toolbox for aquatic animal diseases - a practical manual and software package. ACIAR Monograph. No. 94. 375p.

Flegel T.W. 2006. The special danger of viral pathogens in shrimp translocated for aquaculture. Science Asia. 32: 21 5-231.

Poulos B.T., Tang K.F.J., Pantoja C.R., Bonami J.B., and D.V. Lightner. 2006. Purification and characterization of infectious myonecrosis virus of penaeid shrimp. $J$. Gen. Virol. 87: 987-996.

Poulos B.T. and D.V. Lightner. 2006. Detection of infectious myonecrosis virus (IMNV) of penaeid shrimp by reverse-transcriptase polymerase chain reaction (RT-PCR). Dis. Aquat. Org. 73: 69-72.

Senapin S., Phewsaiya K., Briggs M., and T.W. Flegel. 2007. Outbreaks of infectious myonecrosis virus (IMNV) in Indonesia confirmed by genome sequencing and use of an alternative RT-PCR detection method. Aquaculture. 266: 32-38. 